\title{
10. Sacrilege: From public crime to personal offence
}

\section{lan Hunter}

In this chapter I will be looking at sacrilege in the context of Western European religion and politics in the early modern period. I will be adopting an historical-anthropological approach, with a view to making this discussion of sacrilege comparable with those of people working in other religious and cultural settings. Moreover, there is an important sense in which the societies of early modern Western Europe were themselves multicultural, not just because most contained diverse ethnic 'nations', but more importantly because they contained mutually hostile religious communities. In fact, 'religious cleansing' in early modern Europe provided the prototype for later acts of ethnic cleansing, and the methods by which states attempted to deal with religious conflict led to forms of government still in place today. ${ }^{l}$ This is the context in which I will address my particular theme: how sacrilege was transformed from public crime into personal offence.

Whether sacrilege is possible, and the form in which it takes place, depends upon the disposition of the sacred, of which sacrilege is the violation. And the disposition of the sacred itself varies with the beliefs, doctrines and practices that characterise particular religious cultures. In Western European Christianity, the sacred is understood in terms of the earthly presence of a transcendent divinity. ${ }^{2}$ It is the mediation of this divinity in the world by special persons, places, and things that makes them sacred, and that makes other persons, places and things profane. In this setting, sacrilege occurs when sacred persons, places or things are misused, abused or violated - in short, profaned. Sacrilege thus occurs at the boundary of the sacred and the profane - in transcendent salvational religions like Christianity a particular sharp and fraught boundary-and represents an improper crossing of the boundary itself. Where the boundary also marks the borders of a community - as in the circle of Eucharistic communicants - then sacrilege threatens the community itself (threatens its communication with the divinity) and can result in violent expulsion. ${ }^{3}$ The extent to which the transcendent divinity is manifest in earthly things, and the forms in which this occurs, differ radically between different Christian confessions. Those stressing God's transcendent and supra-human character minimise the forms in which the divinity can be represented or manifested, and may indeed treat such forms - icons, rituals, shrines, priests - as themselves sacrilegious. Those versions of Christianity teaching the mediated presence of God in the world typically treat such icons, rituals, shrines and priests as sacred, 
and view their more puritan or iconoclastic rivals as sacrilegious. But to keep this all in perspective, we need to observe that not all disciplines of life operate the distinction between sacred and profane that gives rise to sacrilege. In non-transcendental arts of living - such as ancient Stoicism and Epicureanism - we find no equivalent category of the sacred, and avoiding sacrilege is treated as a matter of politeness towards those who worship the gods. ${ }^{4}$

Throughout the medieval and early modern period, however, European Christianity was more than just a spiritual locus. It was a formidable earthly force. It exercised direct political and juridical power through an archipelago of armed prince-bishops, the diocesan structure being in fact the footprints left by Christian warriors as they made their way across Europe, stamping out 'paganism' in the early middle ages. ${ }^{5}$ And it exercised indirect power through secular princes, who enforced the law of the most powerful prince-bishop - the bishop of Rome - as part of their exercise of lordship. ${ }^{6}$ Under these circumstances, where there was no clear distinction between the religious and political community or between the Christian and the citizen, sacrilege was both a spiritual transgression and a juridical felony, attracting severe criminal punishment.

We can suggest then that sacrilege emerged as sin and crime in Western Europe as the result of a particular set of cultural and political circumstances: broadly, those of a transcendent sacralising religion exercising overwhelming political and juridical powers, both through its own authority and that of the secular prince or emperor. When these circumstances changed - when in the sixteenth century Western Christendom split into a diversity of churches and then gradually lost its capacity to exercise direct juridical and political power- then sacrilege too was radically transformed. This transformation of sacrilege, which can be characterised as a shift from public crime to personal offence, is what I want to sketch today, in the briefest of terms.

\section{Sacrilege and sacramental violence}

We can begin by quickly indicating how sacrilege - together with the closely associated religious crimes of heresy, blasphemy and witchcraft - took shape in the ecclesial and juridical institutions of late-medieval European Christendom. There are two broad factors to take into account. In the first place, as the obverse of the sacred, sacrilege was a powerful and authentic expression of core Christian sacramental practices, finding expression in both popular devotion and elite theological speculation. A common focus was provided by those earthly things held to be bearers of the transcendent divinity - the church and within the church the Eucharistic host - which, as the most sacred and beneficial of things, were also the most vulnerable to profanation and degradation. Thus, in many parts of late-medieval Europe, as the magical source of God's blessing on the 
community, the host was paraded through the village and fields in early spring to ensure a good harvest. ${ }^{7}$ Concomitantly, the allegation of sacrilegious profanation of the host was the routine way of triggering murderous Christian pogroms against local Jewish communities, non-believers from outside the circle of communicants whose polluting presence threatened communication with God. $^{8}$

Second, if sacrilege was deeply rooted in sacramental religious practice, then during the thirteenth and fourteenth centuries it underwent a major elaboration and codification in canon law, where it was linked to heresy, blasphemy and witchcraft. This was the time at which the university canonists of Northern Italy developed a common legal process for dealing with this array of crimes; a process that could be initiated by denunciation, deployed oaths of veridiction, permitted the regulated use of torture to obtain evidence, denied appeal, and could result in the death sentence. ${ }^{9}$ The extension of canon and Roman law across Western Europe during this period resulted in a centralised system of legal authority, permitting the papacy to exert religious and civil jurisdiction via local clerical and secular authorities. ${ }^{10}$ Sacrilege thus came to be prosecuted in a much more systematic manner and, because of its linkage to heresy, blasphemy and witchcraft, participated in a cross-referring nexus of religious criminality. Heretics were thus routinely denounced as sacrilegious, their guilt being proved by the fact that they performed mock masses, feasted on Eucharistic wafers, broke crucifixes, declared Jesus to be a fraud, and so on. And those on trial for sacrilege were routinely denounced as heretics, their profane acts being indicative of their secret adherence to erroneous and ungodly beliefs.

The presence of the criminal sin of sacrilege in early modern Europe was thus symptomatic of a tightly woven and far-flung matrix of sacramental practices, juridical procedures, and authority structures, anchored ecclesiastically in the papacy and politically in the Holy Roman Empire. Despite the relative civil autonomy of the Northern Italian city states, elsewhere in Europe this matrix resulted in a virtual super-imposition of the sacramental community on the civil community. Threats to the sacramental community resulting from sacrilege, heresy and blasphemy, once proved by the ecclesiastical courts, were subject to the harshest of punishments by the civil authorities. Conversely, threats to civil authority were themselves treated as analogous to sacrilege against the sacred person of the prince, who was God's viceroy on earth. ${ }^{11}$ It is this very superimposition of the sacramental and civil communities, however, that explains the intensity and uncontrollability of the religious-political conflicts that followed from the splitting of the church at the beginning of the sixteenth century. For once the heresy that would become the Protestant church had escaped the juridical and political machinery designed to contain such outbreaks, Protestant 
princes immediately used this machinery to defend their religion against the Roman church.

Given that faith communities were demarcated by the border between the sacred and the profane - between true believers and the heretical monsters - the civil conflicts that erupted across Europe assumed a specifically religious intensity, as those one sought to exterminate were not just political enemies but polluting threats to the sacramental community and its capacity to communicate with God. ${ }^{12}$ Further, this sacramental violence was made all the more difficult to control by the fact that the new religion differed from the old, both in its construction of the sacred and therefore in its sense of sacrilege. The Calvinists in particular stressed the transcendence and inscrutability of God, rejecting the notion of real presence in the Eucharist, and regarding other forms of Catholic immanentism - rituals, processions, pilgrimages, relics - as sacrilegious idolatry, making sacrilege itself into a flashpoint for sacramental violence. In June 1528, for example, the first act of Calvinist iconoclasm in Paris - the vandalising of an image of the Virgin - was answered by an act of Catholic ritual cleansing, as all parishes and the university organised processions to atone for this sacrilege. ${ }^{13}$ Ritual burnings, disembowelments, and massacres were soon to follow as France descended in a series of religious civil wars in which both sides viewed the extermination of the other as necessary for cleansing a spiritual pollution and restoring the purity of the sacramental community.

At the same time, however, the very ferocity of this violence, which threatened the survival of the state itself, led Bodin and the politiques to make the first attempts to separate religious and political community, by developing a secular conception of sovereignty. We can see this in the terms with which the Chancellor Michel de L'Hôpital addressed a peace colloquium during the first war of religion in 1562:

It is not a question of establishing the faith, but of regulating the state. It is possible to be a citizen without being a Christian. You do not cease to be a subject of the King when you separate from the Church. We can live in peace with those who do not observe the same ceremonies. ${ }^{14}$

In fact Chancellor L'Hôpital's words proved to be in vain in the French context, as France would eventually solve the problem of religious conflict by suppressing then eliminating the French Calvinists or Huguenots. Nonetheless, they pointed forward to a profound change - the uncoupling of political governance from Christian spirituality - which would radically transform the character of the sacred and of sacrilege. 


\section{The spiritualising of religion and the desacralising of law and politics}

During the seventeenth century all of the major European powers were faced with the same set of problems: how to achieve religious peace and how to establish stable rule in territories containing bitterly divided religious communities. The measures that evolved to meet these problems-religious toleration being just the tip of the iceberg - would alter the disposition of the sacred and lead to the sidelining of sacrilege (together with heresy and blasphemy) within an increasingly autonomous civil domain. Unfortunately for the historian, these developments differed significantly both within the German Empire and among the other sovereign territorial states, so that there is no typical case. In order to keep my exposition manageable, I will thus focus on developments in the German states - Brandenburg-Prussia in particular - making do with just a few comparative remarks on Britain and France, acknowledging upfront the element of historical bias thus introduced.

The developments that saw the institution of religious peace within the German Empire were piecemeal, protracted, and never fully successful. Nonetheless, we can detect a pattern of development in the century that separated the Religious Peace of Augsburg of 1555 and the more permanent Peace of Westphalia in 1648, which brought an end to the Thirty Years War by declaring that henceforth all three main confessions - Catholicism, Lutheranism and Calvinism-would be recognised and tolerated under imperial law. In his account of this complex process, the German historian of church law, Martin Heckel, points to a number of key elements: the relegation of theology in favour of European public law as the key discourse in the peace negotiations; the gradual acceptance of the permanence of heresy by leading figures, even if the churches would have none of this; and, most important of all, the dropping of religious truth as a criterion for peace in the great treaties, and its replacement by a quite different kind of norm for legitimacy: namely, the attainment of social peace. ${ }^{15}$ In making social peace the prime duty of the sovereign (as opposed to defending the faith or enforcing religious law as God's earthly viceroy) these developments led to a profound secularisation of the political domain. Yet, as Heckel has argued, this was not a secularisation driven by some all-embracing secularist philosophy (in the manner of the French philosophes), but one carried forward by many anonymous jurists and statesmen who remained devoted Christians. ${ }^{16}$ Far from attempting to expunge Christianity, their prime objective was to secure the survival of their own confessions in the face of wholesale religious slaughter. Yet they gradually accepted that for this to happen it would be necessary to separate the church's pursuit of salvation from the state's aim of worldly security. In the case of post-Westphalian Brandenburg-Prussia, this led to a profound dual transformation of the religious and political landscape. On the one hand, 
there was remarkable desacralisation of politics, as jurisconsults and political philosophers attached to the court began to reconstruct the objectives of the state in quasi-Hobbesian terms; that is, in terms of maintaining external and internal security while eschewing all higher level religious and moral aims. On the other hand, there was a no less remarkable spiritualisation of religion, as the Pietists aided by important lay theologians attempted to undermine the whole idea of religious orthodoxy - that is, the idea that salvation was tied to a particular set of theological doctrines and sacramental practices - arguing instead that salvation came rather from a purely personal inner relation to God.

The manner in which this dual desacralisation of politics and spiritualisation of religion transformed the prior construction of sacrilege, heresy, and witchcraft can be seen in the writings of Christian Thomasius, professor of law at the University of Halle in the late seventeenth century, lay theologian, and jurisconsult to the Brandenburg-Prussian court. In his works attacking the legal prosecution of heresy, witchcraft and sacrilege, Thomasius argued along two convergent paths. First, in keeping with his spiritualist theology, he argued that there was no true visible church; that the true church was invisible, known by no outward doctrinal or liturgical signs, and that its members were permanently scattered across the globe. This detachment of salvation from the church removed the theological grounds of heresy and sacrilege by (in effect) denying that God was mediated by specific sacred doctrines or by sacred rituals in holy places. ${ }^{17}$ Second, in keeping with the quasi-Hobbesian conception of politics which he had learned from his mentor Samuel Pufendorf, Thomasius argued that the state had no religious objectives and must be restricted to the ends of maintaining domestic peace and external security. ${ }^{18}$ For this reason there should be no laws against sacrilege, heresy and witchcraft as such, unless the actions associated with them gave rise to violence or civil disorder, in which case they would be punished for that reason, and not because they profaned the community of the faithful. ${ }^{19}$ Unlike his more famous contemporary, John Locke, Thomasius did not base his arguments for toleration on the philosophical notion of natural rights, but on the dual imperatives to spiritualise religion and desacralise the state, whose overarching goal was not personal liberty but the stable governance of multi-confessional societies.

Thomasius thus marks the moment at which, after a century and a half of religious war, the web of canon laws which had tied the political to the religious community began to be unpicked, allowing the persona of the citizen to be differentiated from that of the Christian; although even in Western Europe this moment was neither epochal nor universal. In late-seventeenth century England, religious peace was achieved in a quite different way: not by dismantling the confessional state, but by rebuilding it in a more stable, less persecutory form. This was achieved in accordance with two broad strategies. First, the Anglican church that was to be established as the state religion, was purged of enough 
Anglo-Catholic theology to bring back on board moderate dissenters, providing a stable religious middle ground. Second, using a combination of test acts and toleration acts, non-conforming Protestants and Catholics were excluded from office-holding in the Anglican state, while permitted freedom of private worship. While this set of strategies proved no less successful in securing religious peace than those used in Brandenburg-Prussia, its effect on the laws pertaining to heresy, witchcraft, sacrilege and blasphemy was far less dramatic and uniform. While heresy and witchcraft laws were repealed during the eighteenth century, blasphemy remained a common law crime as a means of protecting the state religion, leading it to form a new juridical series with sedition and obscenity. And it was in this form, as one of a trio of libels - obscene, seditious and blasphemous - that sacrilege maintained a kind of half-life into the modern period of English common law.

\section{Concluding remarks}

Let me conclude by offering a few tentative remarks on how the history I have sketched might bear on current issues, including some of those raised at this conference. I have stressed that the European religious settlements of the late seventeenth century took no single form, and were we to look at France whose settlement had to wait another century, that would only add a third quite different model to those of Germany and England. Nonetheless, despite this, it still makes sense to talk of a broad European-wide movement in which the religious crimes of heresy, sacrilege and blasphemy would lose their status as public crimes. They underwent a sea change, such that the boundary between the sacred and the profane no longer marks the perimeter of the political community but only that of particular religious communities, or sometimes simply particular religious sensibilities.

The historical account offered of this complex of developments should lead us to be sceptical of two modern philosophical and theological attitudes towards the transformations in question. First, it should lead us to question the accounts of toleration given by philosophical liberalism, which seek to ground toleration in the recovery of universal reason and universal subjective rights. As I have already indicated, in Brandenburg-Prussia, Thomasius's arguments for toleration and against heresy, witchcraft and sacrilege laws were grounded not in universal reason and subjective rights, but in an intensely spiritualist theology and a quasi-Hobbesian politics oriented to the desacralisation of the state. Second, for the same reasons, though, we should also be sceptical of philosophical-communitarian accounts of these developments which portray them in terms of the loss of identity-affirming community membership, the emergence of atomised rights-bearing individuals, and a privatisation of religion that would rob political life of depth and meaning. It is true that the undoing of heresy, sacrilege and blasphemy laws gradually allowed for the uncoupling 
of the religious and political communities, but this multiplied rather than diminished the number of communities to which individuals might belong, or the number of personae they might cultivate. Moreover, while it is also true that religion was privatised in the sense of eventually being removed from the coercive apparatus of the state, the threshold of the 'public' that was established - namely, the likelihood of causing civil violence - was high enough to allow for a wide variety of religious institutions and activities to flourish in the civil arena. In fact, the more the state came to approximate a detranscendentalised security envelope, the more it became possible for religious communities to pursue intensely transcendental forms of religious cultivation inside this envelope, without having to fear reprisals from neighbouring communities to whom their version of the sacred might appear sacrilegious.

As a result of the broad developments we have discussed, in those Western European-based jurisdictions where sacrilege and blasphemy laws remained on the books, they lost their sacral character. As these laws evolved in the modern period, it was no longer the violation of persons, things and places inhabited by a transcendent divinity that defined the crime, but something else altogether: the giving of offence in a manner that might lead to civil disorder or violence. Thomasius had already reconstructed the laws pertaining to heresy, blasphemy and witchcraft in this way during the 1690s, in order to prevent their use as weapons of mutual persecution by those who disagreed about the way in which the Christian God inhabited the world. And this broadly is the history of blasphemy law presumed by the New South Wales Law Reform Commission in its Blasphemy Report of 1994; for the Commissioners argue that the key element of the law - that of offensiveness likely to cause civil disturbance-obviates the need for a special law on blasphemy, as this element is well covered by other public-order and anti-discrimination laws. ${ }^{20}$ I would suggest that this kind of recommendation is indicative not of a state of affairs in which society has lost touch with the sacred; rather, it is indicative of one in which the sacred exists only at the level of society - that is, at the level of voluntary religious associations - having been purged from the coercive apparatus of the state as a result of the early modern religious settlements.

\section{ENDNOTES}

1 Wokler, R. 2000, 'Multiculturalism and Ethnic Cleansing in the Enlightenment', in P. G. Ole and R. Porter (eds), Toleration in Enlightenment Europe, Cambridge, Cambridge University Press; Seidler, M. J. 2002, 'Pufendorf and the Politics of Recognition', in I. Hunter and D. Saunders (eds), Natural Law and Civil Sovereignty: Moral Right and State Authority in Early Modern Political Thought, Basingstoke, Palgrave, pp. 235-51.

2 Brown, P. 1982, 'Society and the Supernatural: A Medieval Change', in P. Brown (ed.), Society and the Holy in Late Antiquity, Berkeley, University of Californian Press, pp. 302-32.

3 Schilling, H. 1989, 'Sündenzucht und frühneuzeitliche Sozialdisziplinierung: Die calvinistische, presbyteriale Kirchenzucht', in Emden vom 16. bis 19. Jahrhundert, in G. Schmidt (ed.), Stände und Gesellschaft im Alten Reich, Stuttgart, Franz Steiner Verlag, pp. 265-302. 
${ }^{4}$ Brown, P. 1995, Authority and the Sacred: Aspects of the Christianisation of the Roman World, Cambridge, Cambridge University Press, pp. 34-5.

5 Bartlett R. 1993, The Making of Europe: Conquest, Colonisation and Cultural Change 950-1350, Princeton, Princeton University Press, pp. 5-23.

6 Padoa-Schioppa, A. 1997, 'Hierarchy and Jurisdiction: Models in Medieval Canon Law', in A. PadoaSchioppa (ed.), Legislation and Justice, Oxford, Oxford University Press, pp. 1-15.

7 Baur, J. 1992, 'Lutherische Christologie', H. C. Rublack (ed.), Die lutherische Konfessionalisierung in Deutschland, Gütersloh, Gern Mohn, pp. 83-124.

8 Nirenberg, D. 1996, Communities of Violence: Persecution of Minorities in the Middle Ages, Princeton NJ., Princeton University Press.

9 Trusen, W. 1992, 'Rechtliche Grundlagen des Häresiebegriffs und des Ketzerverfahrens', S. S. Menchi (ed.), Ketzerverfolgung im 16. und frühen 17. Jahrhundert, Wiesbaden, Otto Harrassowitz, pp. 1-20.

10 Padoa-Schioppa, 1997.

11 Kantorowicz, E. 1957, The King's Two Bodies: A Study in Medieval Political Theology, Princeton, N. J., Princeton University Press.

12 Crouzet, D. 1990, Les Guerriers de Dieu. La violence au temps des troubles de religion. Seysell, Champ Vallon.

13 Ramsey, A. W. 1999, Liturgy, Politics, and Salvation: The Catholic League in Paris and the Nature of Catholic Reform, 1540-1630, Rochester NY, University of Rochester Press, p. 8.

14 L'Hôpital, M. de. 1824-5, Oeuvres Completes de Michel de L'Hôpital, I, 425.

15 Heckel, M. 1989, 'Zur Historiographie des Westfälischen Friedens', in K. Schlaich (ed.), Martin Heckel Gesammelte Schriften: Staat, Kirche, Recht, Geschichte, Tübingen, J. C. B. Mohr. I, pp. 484-500; Heckel, M. 1992, 'Religionsbann und landesherrliches Kirchenregiment', in H. C. Rublack (ed.), Die lutherische Konfessionalisierung in Deutschland, Gütersloh, Gerd Mohn, pp. 130-62.

16 Heckel, M. 1984, 'Das Säkularisierungsproblem in der Entwicklung des deutschen Staatskirchenrechts', G. Dilcher and I. Staff (eds), Christentum und modernes Recht. Beiträge zum Problem der Säkularisation. Frankfurt a. M., Suhrkamp, pp. 35-95.

17 Thomasius, C. 1705, 'Ob Ketzerei ein straffbares Verbrechen sei? (An haeresis sit crimen)', C. Thomasius (ed.), Auserlesene deutsche Schriften, Erster Teil, Halle, Renger, pp. 210-307.

18 Thomasius, C. 1701, Dreyfache Rettung des Rechts Evangelischer Fürsten in Kirchen-Sachen, Frankfurt; Thomasius, C. 1705, 'Vom Recht evangelischer Fürsten in Mitteldingen oder Kirchenzeremonien' (De jure principis circa adiaphora, 1695), in C. Thomasius (ed.), Auserlesene deutsche Schriften Erster Teil, Halle, Renger, 1, pp. 76-209.

19 Thomasius, C. 1701, De crimine magiae / Von dem Verbrechen der Zauber- und Hexerey, Halle, Renger.

20 New South Wales Law Reform Commission, 1994, Blasphemy Report 74, Sydney. 